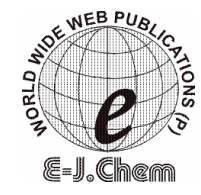

http://www.e-journals.net
ISSN: 0973-4945; CODEN ECJHAO

E-Journal of Chemistry

Vol. 5, No. 1, pp. 39-42, January 2008

\title{
Microwave Induced Synthesis and Anti bacterial Activity of Some 6-(2-Hyroxy phenyl)-4-(substituted phenyl) -3-oxo-2, 3, 4, 5- tetrahydro-1H-indazoles
}

\author{
N. S. RAO, B. BAJIA* Y. K. SRIVASTAVA and RAVINDRA KUMAR \\ Department of Chemistry, M. P. Govt. P.G. College, \\ Chittorgarh-312001.India \\ birbal_bajia@yahoo.com
}

Received 23 March 2007; Accepted 10 May 2007

\begin{abstract}
The title compounds were synthesized by condensation of 2-hydroxy chalcones with ethylacetoacetate to get intermediate 3,5-diaryl-6carbethoxy-2-cyclohexenone which were subsequently treated with hydrazine hydrate to afford the title compounds. All the transformation was carried out under microwave induced conditions. The synthesized compounds were screened for their antibacterial activity in vitro.
\end{abstract}

Keywords Carbethoxy, Cyclohexenone, Microwave irradiation, Antibacterial activity

\section{Introduction}

Microwave assisted organic reaction enhancement (MORE) is now a days a well established technique for synthesis of various heterocycles. All thermally driven reaction can be accelerated by microwave. The spectacular results viz. shorter reaction time, experimental simplicity selectivity of products and easy work up etc were obtained giving clear indication on the potentialities of this technique over conventional heating ${ }^{1-3}$. The reactions under MWI can be carried out under solvent less solid phase making it a environmentally benign process. Thus microwave induced organic synthesis becomes a part of green chemistry ${ }^{4-5}$. Now-a-days it is also termed as e-chemistry because it is easy economic, effective and eco-friendly.

Much attention has been paid to the synthesis of heterocycles containing 1,2-diazole systems like indazole mainly due to their broad spectrum of pharmacological properties. Indazole derivatives possess variety of pharmacological activities such as analgesic ${ }^{7}$ electorseisure $^{7}$, anti inflammatory ${ }^{8,9}$, antidepressant ${ }^{10}$, antitumor ${ }^{11}$, antihypertensive ${ }^{12}$ antiviral ${ }^{13}$ and anticancer ${ }^{14}$ activities. Keeping in view of these findings and usefulness of microwave assisted synthesis, we have synthesized some new 6-(2-hydroxyphenyl) -4-aryl- 
3-oxo-2, 3, 4, 5 tetrahydro-1H indazoles using microwave assisted method. 2-Hydroxy chalcone (a-f) were subjected to michaecl addition with ethyl acetoacetate in presence of either anhy. $\mathrm{K}_{2} \mathrm{CO}_{3}$ /acetone or under solvent free condition using basic alumina ${ }^{15}$ to get 6-5 -diaryl-6-carbethoxy-2-cyclohexenones (2a-f). Compounds (2) were condensate with hydrazine hydrate to afford 6-(2- hydroxy phenyl)-4-aryl -3-oxo-2,3,4,5-tetrahyrdo- $1 \mathrm{H}$ indazoles (3a-f). (Scheme 1, Table 1 and 2)

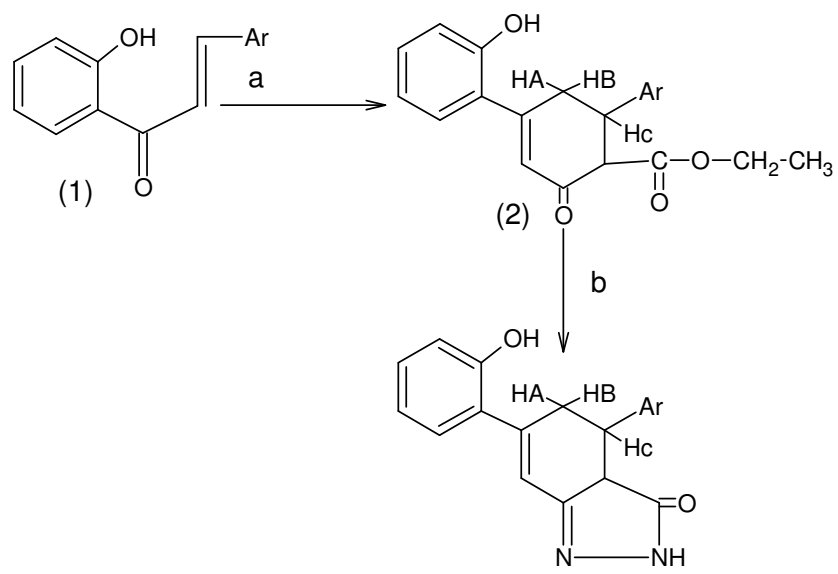

(3)

Reaction conditions and reagents

a. $\mathrm{CH}_{3} \mathrm{COCH}_{2} \mathrm{COOC}_{2} \mathrm{H}_{5} \backslash$ Anhy. $\mathrm{K} 2 \mathrm{CO} 3$ or

$\mathrm{CH} 3 \mathrm{COCH} 2 \mathrm{COOC} 2 \mathrm{H} 5$ /Basic Alumina ,MWI, 5-7 min.

b $\mathrm{NH}_{2} \mathrm{NH}_{2} \cdot \mathrm{H}_{2} \mathrm{O}, \mathrm{MWI}, 4-8 \mathrm{~min}$

Scheme 1.

Table 1. Charactrization data of (2a-f) and (3a-f).

\begin{tabular}{cccccc}
\hline Compd & Ar & $\begin{array}{c}\text { Molecular formula } \\
\text { (M. Wt. })\end{array}$ & $\begin{array}{c}\mathrm{M} \text { P. } \\
{ }^{\circ} \mathrm{C}\end{array}$ & $\begin{array}{c}\text { Yield } \\
\%\end{array}$ & $\begin{array}{c}\text { Reaction } \\
\text { Time, } \\
\text { min }\end{array}$ \\
\hline 2a. & Phenyl & $\mathrm{C}_{21} \mathrm{H}_{20} \mathrm{O}_{4}(336)$ & 154 & 77 & 5.0 \\
2b. & 4-Methoxyphenyl & $\mathrm{C}_{22} \mathrm{H}_{22} \mathrm{O}_{5}(366)$ & 166 & 79 & 6.5 \\
2c. & 3,4-Dimethoxyphenyl & $\mathrm{C}_{23} \mathrm{H}_{24} \mathrm{O}_{6}(396)$ & 174 & 80 & 5.5 \\
2d. & 4-Chlorophenyl & $\mathrm{C}_{21} \mathrm{H}_{19} \mathrm{O}_{4} \mathrm{Cl}(370.5)$ & 176 & 80 & 6.0 \\
2e. & 4- Dimethylaminophenyl & $\mathrm{C}_{23} \mathrm{H}_{25} \mathrm{O}_{4} \mathrm{~N}(379)$ & 152 & 78 & 7.0 \\
2f. & 2-Furanyl & $\mathrm{C}_{19} \mathrm{H}_{18} \mathrm{O}_{5}(326)$ & 140 & 75 & 6.5 \\
3a. & Phenyl & $\mathrm{C}_{19} \mathrm{H}_{16} \mathrm{O}_{2} \mathrm{~N}_{2}(304)$ & 242 & 82 & 5.0 \\
3b. & 4-Methoxyphenyl & $\mathrm{C}_{20} \mathrm{H}_{18} \mathrm{O}_{3} \mathrm{~N}_{2}(334)$ & 219 & 84 & 6.0 \\
3c. & 3,4-Dimethoxyphenyl & $\mathrm{C}_{21} \mathrm{H}_{20} \mathrm{O}_{4} \mathrm{~N}_{2}(364)$ & 200 & 81 & 5.0 \\
3d. & 4-Chlorophenyl & $\mathrm{C}_{19} \mathrm{H}_{15} \mathrm{O}_{2} \mathrm{~N}_{2} \mathrm{Cl}(338.5)$ & 237 & 80 & 5.0 \\
3e. & 4-Dimethylaminophenyl & $\mathrm{C}_{21} \mathrm{H}_{21} \mathrm{O}_{2} \mathrm{~N}_{3}(347)$ & 254 & 80 & 5.0 \\
3f. & 2-Furanyl & $\mathrm{C}_{17} \mathrm{H}_{14} \mathrm{O}_{3} \mathrm{~N}_{2}(294)$ & 231 & 80 & 6.5 \\
\hline
\end{tabular}


Table 2. Antibacterial activity of synthesized compounds(3a-f)

\begin{tabular}{ccccccc}
\hline & & \multicolumn{5}{c}{ Zone of inhibition (diameter in mm) } \\
\hline S.No. & Compound & E.Coli & P.Valgaris & K. Pneumoniae & S.Aureus & S.Albus \\
\hline 1 & 3a & 10 & - & 11 & 13 & 17 \\
2 & $3 \mathrm{~b}$ & 09 & - & - & 15 & 16 \\
3 & $3 \mathrm{c}$ & 12 & - & - & 13 & - \\
4 & $3 \mathrm{~d}$ & 12 & - & 10 & 14 & 13 \\
5 & $3 \mathrm{e}$ & 11 & 10 & 08 & 10 & - \\
6 & $3 \mathrm{f}$ & 10 & 10 & 10 & 11 & - \\
\multicolumn{2}{c}{ Amicacin } & 13 & - & 20 & 20 & 30 \\
\multicolumn{2}{c}{ Coffrioxane } & 23 & 15 & 25 & 21 & 30 \\
\hline
\end{tabular}

The structure of the synthesized compounds was assigned on the basis of their spectral and elemental analysis. The IR spectra of compound (2) showed a broad absorption band at $3600 \mathrm{~cm}^{-1}(-\mathrm{OH}), 3040-2800 \mathrm{~cm}^{-1}(\mathrm{C}-\mathrm{H}$ str. for both aliphatic and aromatic $\mathrm{C}-\mathrm{H})$ and a sharp band at $1730-1700 \mathrm{~cm}^{-1}\left(>\mathrm{C}=\mathrm{O}\right.$ of ester). ${ }^{1} \mathrm{H}-\mathrm{NMR}$ spectra of compounds (2) gave signals at $\delta$ 2.96-2.98 (dd, $\left.1 \mathrm{H}, \mathrm{C}-\mathrm{H}_{\mathrm{A}}\right), 3.06-3.08\left(\mathrm{dd}, 1 \mathrm{H}, \mathrm{C}-\mathrm{H}_{\mathrm{B}}\right)$ and 3.72-3.75 (dd, $\left.1 \mathrm{H}, \mathrm{C}-\mathrm{H}_{\mathrm{C}}\right)$, $4.10\left(\mathrm{q}, 2 \mathrm{H}, \mathrm{CH}_{2}\right), 1.10\left(t, 3 \mathrm{H}, \mathrm{CH}_{3}\right)$ and $6.92-8.01$ ( $m$, aromatic protons)

The IR spectra of compounds (3) gave characteristic bands at $3660-3500 \mathrm{~cm}^{-1}(\mathrm{OH}), 1650$ $\mathrm{cm}^{-1}(>\mathrm{C}=\mathrm{O}), 1595-1580(\mathrm{C}=\mathrm{N})$ and $3200-3190(\mathrm{NH}) .{ }^{1} \mathrm{H}-\mathrm{NMR}$ spectra of compounds (3) gave signals at $\delta$ 2.40-2.70 (dd, $\left.1 \mathrm{H}, \mathrm{C}-\mathrm{H}_{\mathrm{A}}\right), 3.1-3.6\left(\mathrm{dd}, 1 \mathrm{H}, \mathrm{C}-\mathrm{H}_{\mathrm{B}}\right)$ and 3.8-4.11 $\left(\mathrm{dd}, 1 \mathrm{H}, \mathrm{C}-\mathrm{H}_{\mathrm{C}}\right)$ confirming presence of cyclohexenone nucleus. Aromatic protons appeared as multiplate at $\delta 6.67-$ 7.94. The mass spectra of compounds (2) and (3) gave molecular peaks to their molecular masses.

\section{Experimental}

Melting points were measured on a Buchi 530 melting point apparatus in open capillaries and are uncorrected. The purity of the compounds was checked by TLC using silica gel$\mathrm{G}$ adsorbent and benzene-ethyl acetate $(9: 1 \mathrm{v} / \mathrm{v})$ as the eluent. IR spectra were recorded on Perkin-Elmer1600 spectrometer using $\mathrm{KBr}\left(\mathrm{cm}^{-1}\right) .{ }^{1} \mathrm{H}-\mathrm{NMR}$ spectra were taken on Brucker-DRx-600 Spectrometer using TMS as internal standred and $\mathrm{CDCl}_{3}$ or DMSO- $\mathrm{d}_{6}$ as solvent. Mass spectra were obtained on JEOL-SX-DA-600 mass spectrometer (FAB) using $m$-nitro benzyl alcohol as matrix. Matrix peaks appeared at $m / z, 136,137,154,289$ and 307.All the transformation were carried out in domestic microwave oven (Samsung $1630 \mathrm{~N}, 600$ watt, $2450 \mathrm{MHz}$.)

\section{General procedure for synthesis of 3,5-diaryl-6-carbethoxy-2-cyclohexenones(2a-f)}

To slurry of 2-hydroxy chalcone (0.01 mole) and ethyl acetoacetate $\left(0.02\right.$ mole) anhy. $\mathrm{K}_{2} \mathrm{CO}_{3}$ ( 0.04 mole) or basic alumina $(2.0 \mathrm{~g})$ was added and mixed thoroughly. The mixture was air dried and subjected to microwave irradiation for 5-7 minutes. After completion of reaction as indicated by TLC, the reaction mixture was cooled to room temperature and separated solid was extracted with ethanol. The in-organics were filtered off. On standing the filtrate afforded colourless crystals of $2 \mathrm{a}-\mathrm{f}$.

\section{6-(2-Hydroxy phenyl)-4-aryl-3-oxo-2, 3, 4, 5-tetra hydro-1H-indazoles (3a-f)}

6-Carbethoxy cyclohexenones (2a-f, 0.01 mole) and hydrazine hydrate $(0.015$ mole) were mixed thoroughly to form intimate mixture. It was then subjected to microwave irradiation for 4-8 minutes. After completion of reaction as indicated by TLC, the mixture was cooled 
to room temperature and extracted with ethanol. On standing colourless crystals of indazoles separated out which were filtered.

\section{Antibacterial activity}

All the synthesized compounds were screened for their antibacterial activity against gram positive S.aureus and S.albus and gram negative E. Coli, K. pneumoniae and $P$. vulgaris invitro using cup plate agar diffusion method ${ }^{16}$. Zone of inhabitation was measured in $\mathrm{mm}$. Standard drugs used were amicacin and coffrioxane. The screening results are tabulated in Table 2.

\section{Conclusions}

In above synthetic scheme we have used microwave irradiation technique, this is a solvent free reaction condition that leads to considerable saving in the reaction time and energetically profitable. The solvent free condition contributes to saving in cost and diminishes the waste disposal problem. Some compounds show potential antibacterial activity

\section{Acknowledgments}

The authors are highly thankful to Dr. B. L.Verma Retd. Professor of Chemistry, M.L.Sukhadia University, Udaipur for valuable suggestions and guidance. Thanks are also due to Dr. K. P. Madhusudhan, Director SAIF, CDRI, Lucknow for spectral analysis

\section{References}

1. Caddick S, Tetrahedron, 1995, 51, 10403.

2. Verma R S, Green Chemistry, 1999, 43.

3. Gelena S A, Chem. Soc. Rev., 1997, 26, 233.

4. F langa, Delacruz D and A Delahuzu Contemp. Org. Synth., 1997, 373.

5. Bose A K, Manhas M S, Ghosh M and Shah M, J.Org. Chem., 1991, 56, 6968.

6. Bose A K, Banik B K, Lavlinskatia N, Jayaraman M and Manhas M S Chemech, 1997, 27, 18.

7. Jain A C, Mehta A and Arya P, Indian J Chem, 1987, 26B, 150.

8. Palazzo G, Corsi G and Silnerstrini B, J Med Chem, 1996, 9, 38.

9. Bohem R and Hisschelmas R, Pharma Zie, 1980, 35, 232.

10. Charts E R ,Thomas K J and Leo M L, Eur Pat Appl ER, 1992. 509,402,

11. Buydin V G, Colbru N L and Givrdeni A B, J Heterocyclic Chem, 1998, 28, 517.

12. Raman B, Pharmazie, 1990, 45, 214.

13. George V D, Zing L and Bachelerlee T K, J Med Chem, 1998, 41, 2411.

14. Popat K H, Joshi H S, Indian J. Chem, 2003, 42B, 1497.

15. Jhala Y S, dulawat S S and Verma B L, Indian J Chem, 2006, 45(B), 466.

16. Barry A L, Antimicrobial susceptibility test, principle and practices (Illus lea and fehinger, Philedephia USA) 1976, pp 93-108. 


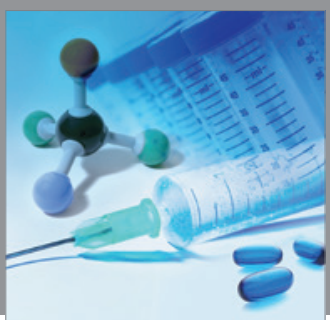

International Journal of

Medicinal Chemistry

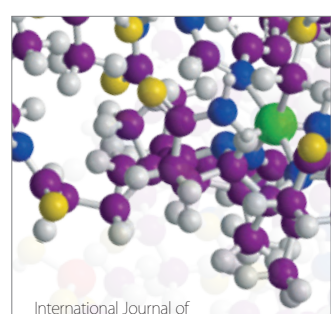

Carbohydrate Chemistry

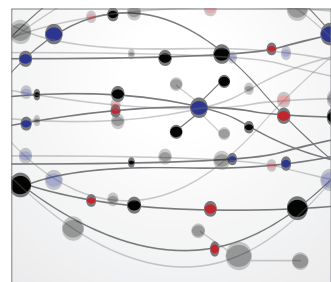

The Scientific World Journal
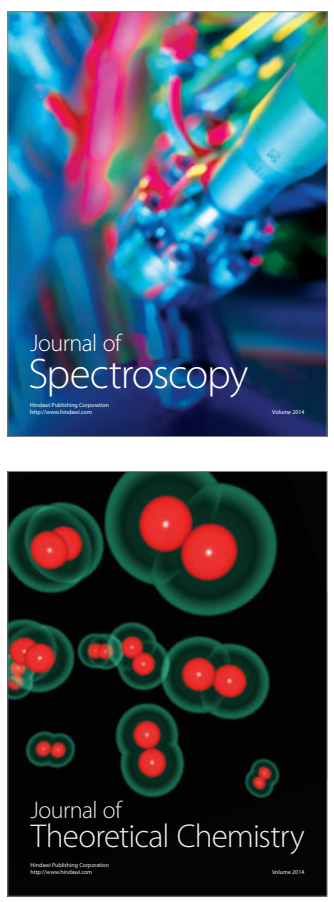
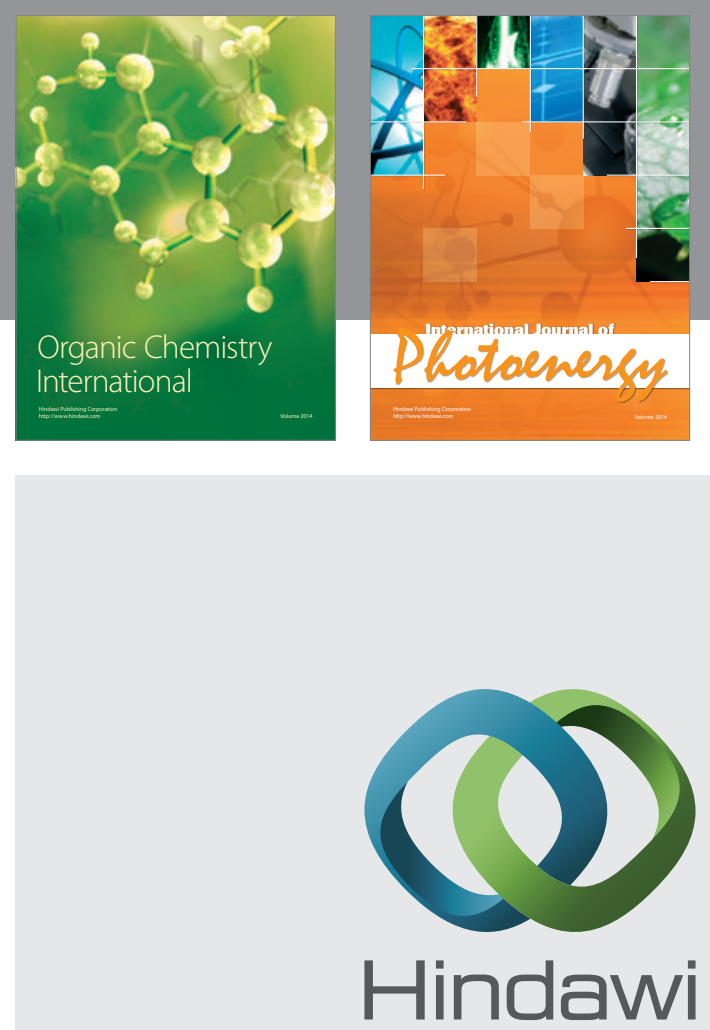

Submit your manuscripts at

http://www.hindawi.com
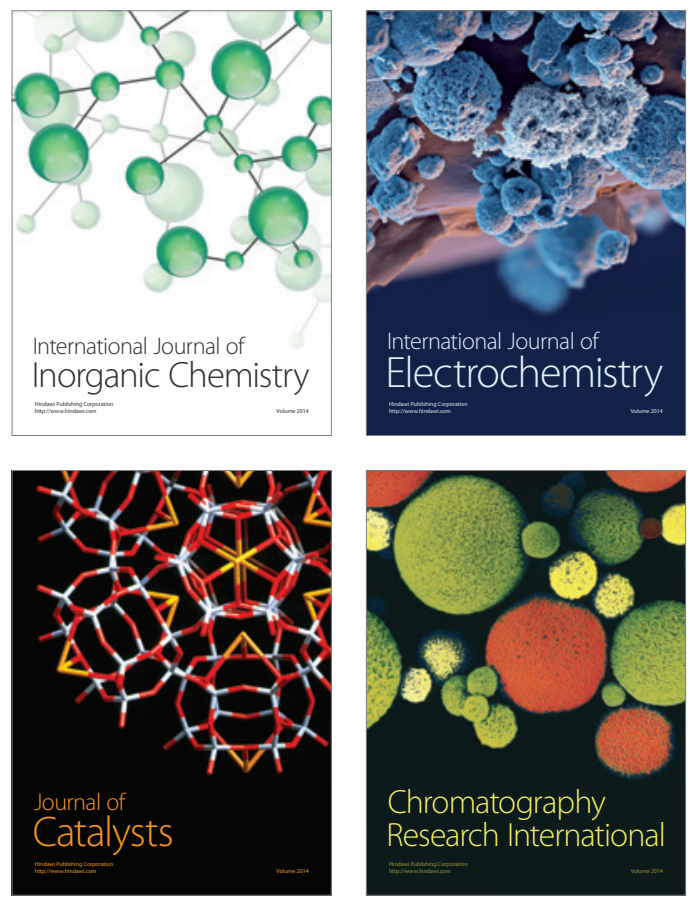
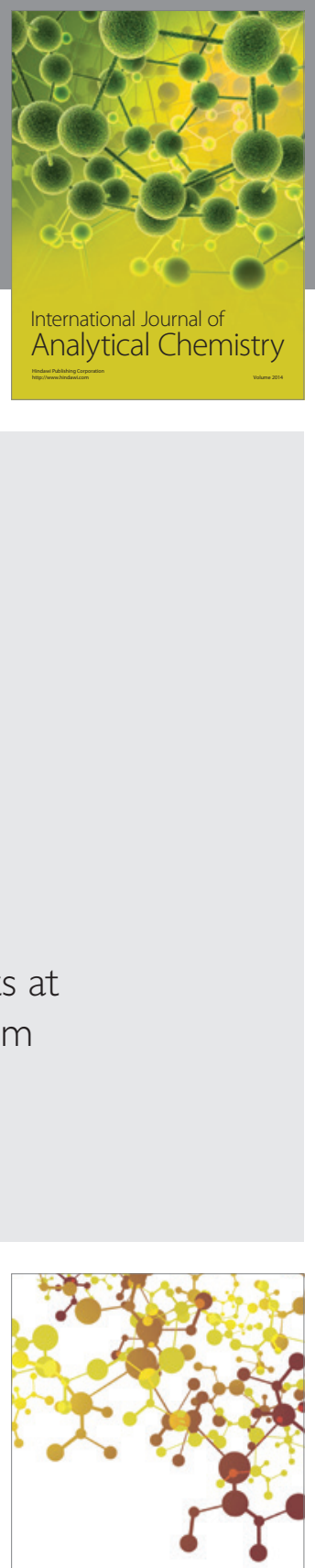

Journal of

Applied Chemistry
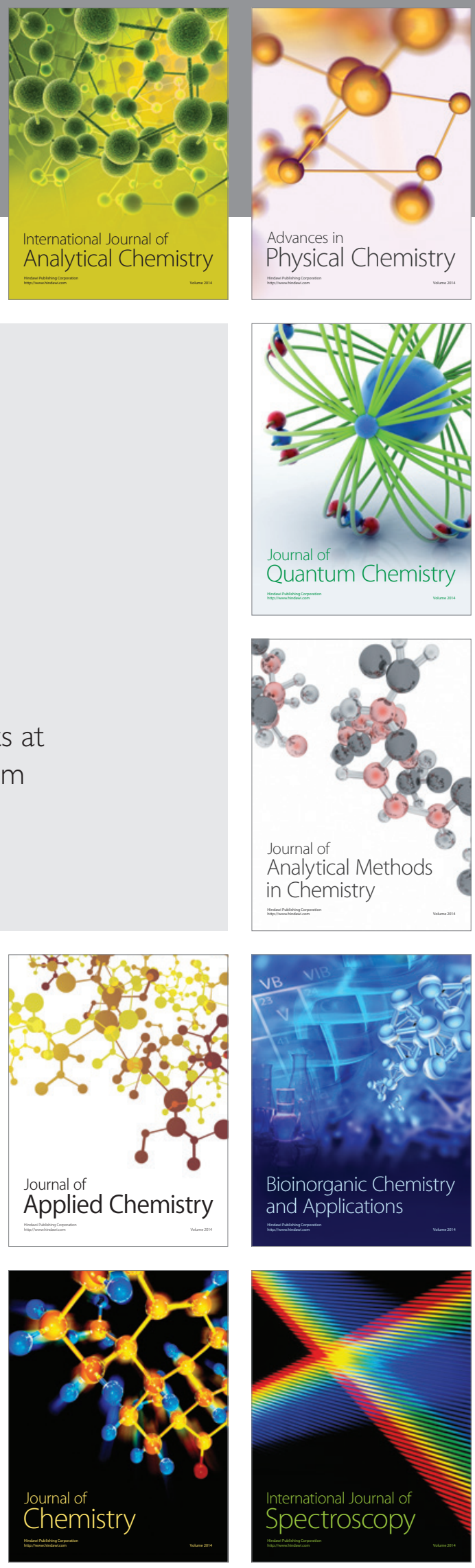